Article history: Submitted 14 February 2021; Accepted 24 April 2021; Available online 1 June 2021.

\title{
Hilangnya Sifat Melawan Hukum Pidana Materil Dalam Tindak Pidana Korupsi Pasca Pengembalian Seluruh Kerugian Keuangan Negara
}

\author{
Yanto Yunus, Juwita Sarri dan Syahiruddin \\ jsarrisingal@gmail.com \\ Universitas Airlangga
}

Keywords:
Loss of Unlawful
Character;
Corruption;
Recovery of State
Losses.

\begin{abstract}
Criminal conduct can be held accountable when it meets two elements of such action as unlawful action and can be reproached. The nature of resisting the law itself is devided into two opposing qualities of formal law and the nature of resisting the law of materiel. The nature of the law regarding material itself has two fuction: itsnegative function and its positive work. Of these functions in application only to its negative (or exempted from the written law) function because of its positive function (an act not prohibited by the law but by society of the act is mistaken) and therefore is a violation of the law. This type of research is the normative study with the constitution approach (statue approach) and the conceptual approach. From this research it can be concluded that the repayment of all financial losses in the state can be excused/fail d; excuse, so that the nature of resisting the laws of materiel's negative function of the perpetrators of corruption is lost. The provision of article 4 of the constitution is judged as irrelevant because the application of a fixed sanction without seeing thr benefits of its ratification. This is based on the theory presented by Nigel Walker and Jeremmy Bentham, which says the application of criminal santions must be ideal and beneficial to the perpetrator.
\end{abstract}

\section{Kata Kunci:}

\section{Abstrak}

Hilangnya

Perbuatan pidana dapat dimintai pertanggungjawaban apabila memenuhi dua Sifat Melawan unsur yakni perbuatan tersebut merupakan perbuatan melawan hukum dan Hukum; Korupsi; perbuatan tersebut dapat dicela. Sifat melawan hukum itu sendiri terbagi dalam Pengembalian dua yakni sifat melawan hukum formal dan sifat melawan hukum materiel, Kerugian Negara. Sifat melawan hukum materiel itu sendiri memiliki dua fungsi yaitu fungsinya yang negatif dan fungsinya yang positif. Dari kedua fungsi tersebut dalam penerapannya hanya diperbolehkan fungsinya yang negatif (atau perbuatan yang dapat dikecualikan dari hukum yang tidak tertulis) dikarenakan fungsinya yang positif (perbuatan yang tidak dilarang oleh undang-undang tetapi oleh masyarakat perbuatan tersebut dianggap keliru) sehingga fungsinya ini dianggap bertentangan dengan undang-undang. Jenis Penelitian ini ialah penelitian normatif dengan pendekatan undang-undang (Statute Approach) dan pendekatan konseptual (Conceptual Approach). Dari penelitian ini dapat disimpulkan bahwa dengan dikembalikannya seluruh kerugian keuangan negara maka perbuatan pelaku dapat dimaafkan/fail d;excuse, sehingga sifat melawan hukum materiel fungsinya yang negatif dari perbuatan pelaku tindak pidana korupsi hilang. Sehingga ketentuan dalam Pasal 4 UU dinilai sudah tidak relevan dikarenakan penerapan sanksi yang tetap dijatuhkan tanpa melihat manfaat dari penjatuhan sanksi tersebut. Hal tersebut berdasarkan pada teori yang dikemukakan oleh Nigel Walker dan Jeremmy Bentham, yang mengatakan bahwa penerapan sanksi pidana harus ideal dan bermanfaat bagi pelaku. 
Yanto Yunus: Hilangnya Sifat Melawan...

\section{Pendahuluan}

Korupsi sebagai salah satu tindak pidana yang dikategorikan sebagai tindak pidana luar biasa (extra ordinary crime) pengolongan tersebut berdasarkan lingkup kejahatannya serta akibat dari tindak pidana korupsi tersebut. Black's Law Dictionary mendefinisikan bahwa The word "corruption" indicates impurity or debasement and when found in the criminal law it means gross impropriety". ${ }^{1}$ (kata korupsi menunjukan ketidakmurnian atau penghinaan dan ketika ditemukan dalam hukum pidana, itu kerusakan moral atau ketidakpantasan yang parah).

Korupsi di Indonesia sudah menjamur dari semua golongan baik dalam sektor Pemerintahan maupun dalam sektor swasta. Baik yang dilakukan oleh pejabat negara maupun yang dilakukan oleh oknum-oknum tertentu yang mempunyai jabatan di perusahan-perusahan swasta, selain itu kasus korupsi di Indonesia penanganannya dilakukan secara khusus. Kekhususan inipun menjadi cikal bakal dibentuknya Komisi Pemberantasan Korupsi (KPK). Dengan dibentuknya KPK menunjukan keseriusan Indonesia untuk bisa memberantas semua tindak pidana korupsi. Tindak Pidana Korupsi itu pun bisa dikatakan tindak Pidana yang bersifat/bernilai ekonomis, dikarenakan korupsi tersebut pada umumnya berkaitan dengan suatu yang membawa keuntungan baik berupa nilai ekonomi (uang/aset) bahkan berupa jabatan. Semuanya itu mempunyai satu tujuannya yakni untuk menguntungkan diri sendiri atau kelompok dengan cara melawan hukum. Kejahatan korupsi sangat berdampak bagi semua sektor, terutama dalam perekonomian negara. Karena dengan kerugian yang ditimbulkan dari korupsi terhadap keuangan negara, maka negara dalam menjalankan roda pemerintahan menjadi terhambat dan tidak maksimal.

Korupsi sendiri secara khusus diatur di dalam Undang-Undang Nomor 31 Tahun 1999 tentang Pemberantasan Tindak Pidana Korupsi, dalam penanganan setiap perkara korupsi penuntut umum sering menerapkan Pasal 2, Pasal 3 dan Pasal 4. Pasal-Pasal ini menjadi Pasal pamungkas oleh penuntut umum untuk bisa

${ }^{1}$ Bryan A Garner, Black's Law Dictionary (9th edn, 2010). 
menjerat perlaku korupsi untuk dapat mempertanggungjawabkan perbuatannya. Dari Pasal tersebut memunculkan pertimbangan-pertimbangan hakim yang beragam dalam memutus setiap perkara korupsi. Keragaman pertimbangan hakim terkait penafsiran Pasal 4 UU No. 20 Tahun 2001 Tentang Perubahan atas UU No. 31 Tahun 1999 Tentang Pemberantasan Tindak Korupsi (Tipikor)² dalam ketentuan Pasal 4 yang menentukan bahwa, pengembalian kerugian keuanagan negara atau perekonomian negara tidak menghapuskan pidananya pelaku tindak pidana sebagaimana dimaksud dalam Pasal 2 dan Pasal 3. Penerapan Pasal 4 ini dalam perkara Tipikor sering mengundang kontroversi, hal ini dikarenakan sampai sekarang masih menjadi problematika/isu yang sering diperdebatkan baik dalam kalangan akademisi maupun praktisi hukum mengenai apakah dengan dikembalikannya seluruh kerugian keuangan negara maka dapat menghilangkan sifatmelawan humum materiel.Pengembaliankeuangannegara tersebutbisa dilihat dalam Putusan Pengadilan Negeri Kelas IA Khusus Surabaya, Putusan nomor 57/ Pid.Sus/TPK/2014/PN SBY, tanggal 3 Juli 2014. Dalam pertimbangan hukum dari majelis hakim dengan dikembalikannya uang Sebesar Rp. 25.000.000 dari kerugian negara sebesar Rp. 104.000.000. Maka hal tersebut menurut majelis hakim masuk dalam hal-hal yang meringankan. Bertitik tolak dari Putusan Mahkamah Konstitusi Nomor 25/PUU-XIV/2016 yang memutuskan bahwa tindak Pidana Korupsi bukan lagi merupakan tindak pidana formil tetapi merupakan tindak pidana materil. Sehingga harus adanya akibat yang dilarang oleh undang-undang "kerugian negara". Namun apabila dalam suatu tindak pidana korupsi dilakukan pengembalian seluruh kerugian negara apakah memungkinkah hapusnya sifat melawan hukum materil dalam fungsinya yang negatif. Berdasarkan pemaparan diatas penulis menemukan isu hukum yang menarik untuk dilakukan penelitian secara kritis terkait apakah dengan pengembalian seluruh kerugian negara dapat menghapus sifat melawan hukum tindak pidana korupsi?.

${ }^{2}$ Undang-Undang No 20 Tahun 2001 tentang Perubahan atas Undang-Undang No. 31 Tahun 1999 tentang Pemberantasan Tindak Pidana Korupsi, Selanjutnya dalam Penelitian ini disingkat (UU Tipikor). 


\section{Metode Penelitian}

Jenis Penelitian yang diggunakan adalah penelitian hukum, dengan menggunakan pendekatan undang-undang(Statute approach) yakni menelah semua undang-undang dan regulasi yang berkaitan dengan isu hukum. ${ }^{3}$ Pendekatan konseptual (Conceptual Approach) menelaah terkait prinsip atau pandangan yang dikemukakan oleh ahli atau doktirn hukum yang terkenal, serta konsep-konsep yang tidak terdapat dalam undang-undang ataupun di dalam putusan-putusan pengadilan. ${ }^{4}$

\section{Pembahasan}

Tindak pidana korupsi merupakan kejahatan yang selalu diperangi oleh pemerintah. Salah satu alasan pemerintah sangat serius untuk memerangi kejahatan korupsi antara lain:

1. Menjaga agar aset negara (keuangan negara) tidak dipindahtangankan menjadi milik pribadi, untuk kepentingan pribadi atau kelompok dengan melawan hukum;

2. Mencegah munculnya kekuasaaan-kekuasaan yang kotor dan tidak bersih;

3. Menjamin kesejahteraan dan kepentinmgan bersama masyarakat.

Namun hal-hal yang sering diperdebatkan sekarang ini adalah apabila dengan dikembaliknya kerugian yang ditimbulkan oleh pelaku secara menyeluruh maka kerugian negara (keuangan negara) maka negara tidak lagi dirugikan. Untuk bisa menjelaskan akan perdebatan dan pertanyaan yang sering muncul dalam masyarakat maka sebelumnya penulis akan memaparkan konstruksi berpikir penulis sebagai berikut:

\section{Konsep Sifat Melawan Hukum}

Pengertian perbuatan melawan hukum semulanya di adopsi dari Hukum Perdata. Secara terminologi perbuatan melawaan hukum dalam bahasa belanda

\footnotetext{
${ }^{3}$ Peter Mahmud Marzuki, Penelitian Hukum (Kencana 2005).[133].

4 ibid.[178-180].
} 
dikenal dengan (wederrechtelijk) yang lebih sering digunakan dalam hukum pidana sedangkan dalam hukum perdata (onrechtmatig). ${ }^{5}$ Kedua istilah tersebut sering membawa perdebatan terkait perbuatan melawan hukum baik dalam bidang pidana maupun di dalam bidang perdata. Seperti yang dikemukakan oleh Apeldoorn, mengenai alasan-alasan yang timbul dari pembedaan kedua bidang ini adalah sebagai berikut:

1. Peran Pemerintah dalam masyarakat;

2. Hukum melayani tujuan-tujuan yang berlainan dan kepentingan-kepentingan yang berbeda. ${ }^{6}$

Sifat melawan hukum itu sendiri merupakan salah satu unsur dari perbuatan melawan hukum. Unsur tersebut merupakan suatu penilaian objektif terhadap perbuatan dan bukan terhadap si pembuat. ${ }^{7}$

Rutten mengemukakan bahwa:

"Perbedaan yang hakiki adalah bahwa hukum pidana langsung mengenai pemerintah, sedangkan pengaturan tentang perbuatan melawan hukum, pertama-tama bertujuan melindungi kepentingan individu dan sejauhnya mengenai kertertiban umum. Peraturan perundang-undangan memberikan dasar yang berbeda, baik dia yang melakukan perbuatan melawan-hukum, maupun dia yang melakukan tindak pidana berbuat bertentangan dengan larangan dan yang diperintahkan". ${ }^{8}$

Dari perdebatan yang panjang terkait pandangan dari arti melawan hukum itu sendiri maka dikunci dengan pandangan yang diberikan oleh Van Bemmelen yang menyatakan bahwa, arti melawan hukum itu sendiri tidak ada bedanya baik yang ada dalam bidang pidana maupun di dalam bidang perdata, ${ }^{9}$ seperti dalam Pasal 1365 KUHPerdata bahwa, “tiap perbuatan melanggar hukum, yang membawa kerugian kepada orang lain, mewajibkan orang yang karena salahnya

${ }^{5}$ Komariah Emong Sapardjaja, Ajaran Sifat Melawan Hukum Materiel Dalam Hukum Pidana Indonesia, (Alumni 2002),[90].

${ }^{6}$ ibid.[46].

${ }^{7}$ Titin Apriani, 'Konsep Perbuatan Melawan Hukum Dalam Tindak Pidana' (2019) 13 GARA.[42].

8 ibid.[42].

${ }_{9}$ Komariah Emong Sapardjaja, Op.Cit.[33]. 
Yanto Yunus: Hilangnya Sifat Melawan...

menerbitkan kerugian itu, mengganti kerugian tersebut".${ }^{10}$ Sehingga mendapat perbedaan istilah tersebut baik dalam bidang pidana maupun perdata tentunya tidak membedakan arti melawan hukum.

Sifat melawan hukum sendiri seperti dikutip dalam buku hukum pidana yang ditulis oleh D. Schaffmeister, N. Keijzer dan Sutorius yang mengemukakan 4 jenis Sifat melawan hukum :

a. Sifat melawan hukum umum, adalah suatu syarat yang umum yang bisa dikenakan kepada pelaku atas perbuatan yang dilakukan memenuhi rumusan delik sehingga perbuatan tersebut dapat dicela;

b. Sifat melawan hukum khusus, pencatuman dari sifat melawan hukum dalam rumusan delik sebagai contoh Pasal 362 KUHP, yang bisa kita lihat terdapat frasa "dengan maksud memiliki secara melawan hukum". Sehingga sifat melawan hukum khusus ini menyatu dalam rumusan delik;

c. Sifat melawan hukum formil, adalah perbuatan yang dilakukan oleh pelaku sudah memenuhi semua rumusan delik yang didakwakan kepadanya;

d. Sifat melawan hukum materil, adalah perbuatan yang dilakukan, membahayakan dan merugikan kepentingan hukum yang hendak dilindungi oleh pembuat undang-undang dalam suatu rumusan delik tertentu. ${ }^{11}$

Sifat melawan hukum formil menurut Indrianto Seno Adji, adalah apabila keseluruhan delik sudah terpenuhi atau dapat dibuktikan, maka perbuatan itu sudah bisa dikategorikan sebagai perbuatan yang melawan hukum. (sifat melawan hukum formil ini erat kaitanya dengan asumsi bahwa hukum adalah undang-undang) asumsi tersebut asumsi yang dianut oleh Simson. ${ }^{12}$ Asumsi tersebut sangat berkaitan dengan peryataan yang sering dikemukakan atau yang dilihat oleh kebanyakan orang bahwa hukum sebagai undang-undang seperti dengan pembagian orang dalam memandang hukum seperti yang dikemukakan oleh Apeldoorn (De ontwikkelde Leek) dan (The Man in the street).

Sifat melawan hukum materil, adalah perbuatan yang bertentangan dengan rumusan delik (tertulis) tetapi juga yang bertentangan dengan pergaulan yang ada, atau pergaulan yang hidup dan berkembang di dalam masyarakat. Di Belanda

\footnotetext{
${ }^{10}$ R. Subekti dan Tjitrosudibio, Kitab Undang-Undang Hukum Perdata (PT. Pradnya Paramita 2004).[346].

${ }^{11}$ E PH Sutorius D. Schaffmeister, N.Keijzer, Hukum Pidana (Konsorsium Ilmu Hukum 1995).[39].

${ }^{12}$ KPHA Tjandra Sridjaja Pradjonggo, Sifat Melawan Hukum Dalam Tindak Pidana Korupsi (Indonesia Lawyer Club 2010).[57].
} 
sendiri terkait dengan sifat melawan hukum materil seperti dalam kasus yang terkenal yaitu kasus lindenbaum Cohen Arrest (Arrest H.R Nederlaand 1919) yang kemudian dari kasus tersebut menurut Hoge Raad, perbuatan melanggar hukum (onrechtmaticgedaad) tidak hanya perbuatan yang bertentangan dengan undangundang saja tetapi perbuatan yang bertentangan dengan pergaulan masyarakat yang tidak patut.

Didik Endero P. Dalam bukunya Hukum Pidana Untain Pemikiran memberikan penjelasan secara terperinci mengenai pembagian fungsi sifat melawan hukum materil sebagai berikut: ${ }^{13}$

a. Fungsi yang negatif, sebagai alasan penghapus pidana dari suatu perbuatan yang diluar undang-undang, artinya bahwa suatu perbuatan tersebut dilarang oleh undang-undang. Akan tetapi, perbuatan tersebut dapat dikecualikan oleh hukum yang tidak tertulis, yakni kepatutan dalam pergaulan dalam masyarakat. Sehingga perbuatan tersebut tidak dapat dicela atau hilang sifat melawan hukumnya dan bukan lagi sebagai tindak pidana;

b. Fungsi positif, adalah perbuatan yang oleh undang-undang tidak dilarang, tetapi dilarang atau dianggap keliru oleh masyarakat. Dan tetap dapat dipidana, fungsinya yang positif ini bertentangan dengan Asas legalitas.

\section{Kontradiksi Putusan Hakim Dalam Penerapan Sifat Melawan Hukum Materiel Dalam Tindak Pidana Korupsi}

Dalam undang-undang No. 31 Tahun 1999 Tentang Tindak Pidana Korupsi yang di dalamnya terdapat 30 bentuk atau jenis tidak pidana korupsi, yang apabila dikelompokan menjadi 7 kelompok yakni:
a. Kerugian terhadap keuangan negara;
b. Suap;
c. Penggelapan dalam jabatan;
d. Pemerasan;
e. Perbuatan curang;

${ }^{13}$ Didik Endro Purwoleksono, Hukum Pidana Untaian Pemikiran (Airlangga University Press 2019).[184]. 
f. Benturan kepentingan dalam pengadaan;

g. Gratifikasi. ${ }^{14}$

Darijenis tindak pidana korupsi diatas dalam penelitianini penulis mengkhususkan pada tindak pidana korupsi yang merugikan keuangan negara. Jenis korupsi ini dalam UU Tipikor diatur dalam Pasal 2 dan Pasal 3. Dalam Ketentuan Pasal 2 dan Pasal 3 menentukan bahwa:

Pasal 2

(1). Setiap orang secara melawan hukum melakukan perbuatan memperkaya diri sendiri atau orang lain atau suatu korporasi yang dapat merugikan keuangan negara atau perekonomian negara, dipidana dengan penjara paling singkat 4 tahun dan paling lama 20 tahun dan denda paling sedikit Rp. 200.000.000 dan paling banyak Rp. 1.000.000.000.

(2) dalam hal tindak pidana korupsi sebagaimana dimaksud dalam ayat (1) dilakukan dalam keadaan tertentu, pidana mati dapat dijatuhkan

Pasal 3

"Setiap orang yang dengan tujuan menguntungkan diri sendiri atau orang lain atau suatu korporasi, menyalahgunakan kewenangan, kesempatan atau sarana yang ada padanya karena jabatan atau kedudukan yang dapat merugikan keuangan negara atau perekonomian negara, dipidana dengan pidana penjara seumur hidup atau pidana penjara paling singkat 1 tahun dan paling lama 20 tahun dan atau denda paling sedikit Rp. 50.000 .000 dan paling banyak Rp. 1.000.000.000"

Dari kedua Pasal diatas bisa dilihat di dalam Pasal 2 unsur sifat melawan hukum tersirat dalam rumusan delik. Dalam kedua Pasal di atas yang menjadi perdebatan yakni terkait sifat melawan hukum materil atau formil yang termuat di dalam ketentuan diatas. Dalam Ketentuan Pasal 2 dan Pasal 3 terdapat keragu-raguan oleh para penegak hukum. Keraguan tersebut terkait apakah Perbuatan Melawan hukum dalam UU Tipikor dikatregorikan sebagai Sifat Melawan Hukum Materil atau sifat melawan hukum Formil.

D. Schaffmeister, Nico Keijzer, dan E PH. Sutorius, yang memandang bahwa makna materil merupakaan sifat atau hakikat dari perbuatan terlarang dalam undang-undang atau dalam perumusan delik tertentu, yang kemudian

${ }^{14}$ KPHA Tjandra Sridjaja Pradjonggo, Op.Cit.[109-110]. 
mengatakan bahwa Sifat Melawan Hukum Formil berarti, sudah dipenuhinya semua syarat tertulis dalam rumusan delik sehingga kepada pelaku dapat dijatuhi pidana, sedangkan sifat melawan hukum materil, adalah perbuatan yang dilakukan dengan melanggar hukum membahayakan kepentingan hukum yang hendak dilindungi oleh pembentuk undang-undang dalam rumusan delik tertentu. ${ }^{15}$

Pandangan kedua yang melihat makna Materil dari sumber hukumnya. Pandang ini melihat sifat melawan hukum formil sebagai hal-hal yang bertentangan dengan undang-undang (tertulis), sementara sifat melawan hukum materil adalah hal-hal yang bertentangan dengan hukum yang ada dalam masyarakat (living law), serta bertentanag dengan asas, nilai-nilai kepatutan dalam masyarakat itu sendiri. ${ }^{16}$ Dari kedua pandangan tersebut memberikan argument-argument terkait kriteria materiel yakni:

1. Menilai atau memberikan penafsiran materil terhadap perbuatan atau kepentingan hukum yang hendak dilindungi oleh pembuat undang-undang dalam perumusan delik tertentu, serta menghapus atau meniadakan sifat melawan hukum formil yang telah ditetapkan dalam undang-undang menjadi Sifat melawan hukum materil yang hanya digunakan dalam fungsi negatifnya sebagai alasan pembenar, atau alasan pemaaf;

2. Pandangan kedua berpendapat bahwa sifat melawan hukum materil itu sendiri tidak hanya memberikan penilaian terhadap perbuatan yang telah ditetapkan atau sudah dirumuskan dalam undang-undang (hukum tertulis), tetapi juga terhadap perbuatan yang oleh undang-undang tidak ditentukan atau diluar undang-undang (tidak tertulis). ${ }^{17}$

Pandangan-pandangan yang sudah penulis kemukakan diatas nampaknya membawa pengaruh terhadap konsistensi hakim dalam membuat suatu pertimbangan hukum dalam perkara tindak pidana korupsi. Hal tersebut dapat

\footnotetext{
${ }^{15}$ ibid. [174].

${ }^{16}$ ibid.[175].

17 ibid.
} 
Yanto Yunus: Hilangnya Sifat Melawan...

kita lihat bahwa terdapat putusan-putusan hakim yang menerapkan sifat melawan hukum materil baik dalam fungsi negatif maupun dalam fungsi yang positif.

Penerapan sifat melawan hukum dengan fungsinya yang negatif terdapat dalam Putusan Mahkamah Agung Republik Indonesia No. 42 K/Kr/1965 dalam perkara Mahroes Efendi. Dalam pertimbangan hukum dari hakim mengatakan bahwa "suatu tindakan pada umumnya dapathilang sifatmelawan hukumnya bukan semata-mata hanya berdasarkan pada ketentuan dalam perundang-undangan, melainkan berdasarkan pada asas-asas keadilan atau asas-asas hukum yang tidak tertulis dan bersifat umum" melihat dari pertimbangan hakim bahwa perbuatan terdakwa sesunguhnya menyimpang dari tujuan awal yang telah ditentukan akan tetapi perbuatan terdakwa tersebut jika ditinjau dari sudut kemasyarakatan, maka perbuatan terdakwa justru merupakan wujud pelayanan yang menguntungkan masyarakat dan dapat disebut juga untuk melayani kepentinmgan umum. ${ }^{18}$

Penerapan sifat melawan hukum materil dalam fungsinya yang positif dapat dlihat dalam Putusan No. 275 K/Pid/1983. ${ }^{19}$ Dengan terdakwanya Raden S. Natalegawa, yang mana sebelumnya hakim Pengadilan Tinggi memberikan pertimbanagan hukum atas putusan yang diputus oleh Pengadilan Negeri Jakarta Pusat yang membebaskan terdakwa dengan pertimbangan bahwa dalam perkara tersebut tidak dapat dibuktikannya unsur melawan hukum. Namun pendapat yang berbeda diberikan oleh Mahkamah Agung melalui putusan Mahkamah Agung No. 275 K/Pid/1983 Mahkamah berpendapat bahwa putusan bebas yang dijatuhkan oleh Pengadilan Negeri Jakarta Pusat adalah keliru karena yang tidak terbukti bukan sifat melawan hukunya akan tetapi penafsiran suatu istilah yang tidak dapat dibuktikan. Sehingga Mahkamah Agung sependapat dengan kejaksaan bahwa putusan yang diberikan oleh Pengadilan Negeri Jakarta Pusat bertentangan dengan Asas Legalitas, serta Putusan bebas tersebut menjadi putusan bebas yang tidak murni. ${ }^{20}$

${ }^{18}$ Didik Endro Purwoleksono, Op.Cit.[183].

${ }^{19}$ ibid.[185].

${ }^{20}$ Surat Kejaksaan Agung Republik Indonesia, No. B-201/f/Fpt/5/199 Jakarta Tanggal 04 Mei Tahun 1990, Perihal; Petunjuk Penyusunan Memori Kasasi atas Putusan Bebas. 


\section{Hilangnya Sifat Melawan Hukum Meteriel}

Sifat melawan hukum itu sendiri seperti yang sudah penulis paparkan diatas pada dasarnya dikatakan sebagai sifat/perbuatan melawan hukum apabila, perbuatan tersebut dilarang dan ketentuannya diatur dalam rumusan delik (hukum tertulis, atau perbuatan tersebut sekalipun tidak diatur dalam peraturan perundangundangan akan tetapi perbuatan tersebut tentunya melanggar moral, nilai-nilai yang hidup dalam masyarakat. Sehingga dari jenis ini bisa dilihat ada satu kepentingan yang hendak dilindungi, yakni nyawa, badan atau tubuh, kemerdekaan, kehormatan dan harta benda. Selain itu, apa bila dihubungkan dengan kasus korupsi, maka kepentingan yang hendak dilindungi adalah kepentingan negara dalam hal ini keuangan negara yang dirugikan akibat perbuatan pelaku korupsi. Hukum itu sendiri melalui perwujudannya yang tertulis berupa undang-undang, ataupun yang tidak tertulis yakni nilai-nilai yang hidup, yang tetap mempunyai tujuan yang sama yakni, keadilan, kepastian dan kemanfaatan.

Tujuan hukum selain berdasarkan pada tiga tujuan utama diatas, tujuan hukum juga mempunyai cita-cita untuk menjaga dan melindungi kepentingan masyarakat serta tujuan yang paling luhur yaitu apa yang nantinya akan kembali dan dirasakan dari masyarakat yaitu keadilan dan apakah keadilan tersebut membawa kemanfaatan bagi masyarakat. Tujuan hukum selain memberikan keadilan dan kepastian ada suatu tujuan yang penting yaitu kemanfaatan hukum yang sering dikesampingkan oleh kebanyakan kalangan. Penulis mengambil contoh terkait sanksi pidana penjara yang diberikan kepada pemakai narkotika. Penjatuhan sanksi menjadi tidak tepat, karena pemakai tersebut seharusnya direhabilitasi. Sekarang kebanyakan orang mempunyai persepsi bahwa halhal yang berkaitan dengan kejahatan maka akan berujung pada pidana penjara. Sehingga banyak orang yang melihat bahwa pemidanaan merupakan langkah yang efektif untuk para pelaku kejahatan.

Sanksi pidana berfungsi sebagai langkah terakhir (Ultimum Remedium) yang akan diterapkan apabila sudah dilakukan berbagai cara namun tidak mampu memberikan efek jera / tidak efektif, sehingga dengan keadaan tersebut maka 
Yanto Yunus: Hilangnya Sifat Melawan...

bisa diterapkannya sanksi pidana penjara. Sebagai langkah terakhir menunjukan bahwa sanksi pidana bukanlah satu-satunya sanksi yang dapat dijerat atau dapat dikenakan kepada pelaku misalnya, dapat dikenakan sanksi administrasi (untuk kasus korporasi, cth pencabutan izin perusahaan), sanksi yang berwarna perdata seperti ganti rugi (untuk kasus lakalantas, cth biaya perbaikan mobil, atau menan ggung biaya rumah sakit) sehingga lebih mengarahkan kepada hal-hal yang mudah diselesaikan dan tetap memberikan kemanfaatan kepada masing-masing pihak. Seperti contoh kasus lakalantas apabila Pelaku ditahan maka siapa yang akan memberikan ganti kerugian, atau membiayai seluruh kerugian yang timbul dari perbuatannya.

a. Hilangnya sifat melawan hukum materiel dengan fungsinya yang positif.

Sifat melawan hukum seperti yang sudah penulis kemukakan diatas bahwa suatu perbuatan dapat dikatakan memenuhi unsur melawan hukum apabila perbuatan itu merupakan perbuatan yang melawan hukum dan perbuatan tersebut dapat dicela. Hilangnya sifat melawan hukum materiel dengan fungsinya yang positif di Indonesia sendiri seperti yang sudah penulis singgung dimuka terkait dengan Kasus Putusan No. 275 K/Pid/1983 Raden Natalegawa terkait kasus tersebut dalam Putusan Mahkamah agung diatas sesuai dengan penulis kemukakan diatas tentang pertimbangan hakimnya. Yang memperdebatkan terkait pendapat hakim judex factie mengenai tidak terpenuhinya unsur dalam kasus tersebut.

Dari putusan Pengadilan yang membebaskan Raden Natalegawa, yang kemudian dengan adanya Putusan Mahkamah Agung No. 275 K/Pid/1983 dari pertimbangan hakim dan pendapat kasasi yang memberikan pendapat bahwa Putusan bebas yang dijatuhkan oleh Pengadilan Negeri merupakan Putusan bebas tidak murni. Dari kasus ini yang dikatakan bebas tidak murni disini karena tidak terbuktinya suatu unsur/ sementara bebas murni ialah terbuktinya suatu unsur. Akan tetapi pertimbangan hukum Pengadilan Negeri menyatakan bahwa unsur yang disangkahkan tidak terbukti sementara pertimbangan Mahkamah Agung menyatakan bahwa dengan bebasnya Raden 
Natalegawa maka secara tidak langsung telah diterappak hilangnya sifat melawan hukum materiel yang positif.

Penerapan hilangnya sifat melawan hukum dengan fungsi yang positif tentunya bertentangan dengan Asas Legalitas (Priciple of legality) yang termuat dalam Pasal 1 ayat (1) KUHP. Karena dengan diterapkannya hilangnya sifat melawan hukum dengan fungsi yang positif maka menurut Vos, Hakim telah melakukan penerapan penafsiran yang analogi. ${ }^{21}$

b. Hilangnya Sifat Melawan Hukum Materiel dengan fungsinya yang Negatif.

Hilangnya sifat melawan hukum itu sendiri bukanlah merupakan hal baru yang terjadi dalam peradilan Indonesia bisa dilihat dalam Putusan yang terkenal yakni Putusan Mahkamah Agung RI, tanggal 8 Januari 1966 No. 42K/ Kr/1965 dalam Perkara Machroes Effendi (ME) yang terbukti melakukan tindak pidana seperti yang dirumuskan di dalam Pasal 372 Jo Pasal 64 ayat (1) KUHP yang dilakukan secara berualang-ulang kali. Dalam kasus tersebut pada pokok perkaranya sebagai berikut (ME) sebagai patih di kantor Bupati Sambas telah mengeluarkan DO Gula insentif padi yang menyimpang dari tujuannya, yang mana gula tersebut hanya bisa dikeluarkan dalam rangka pembelian padi untuk pemerintah. Tapi (ME) menggeluarkan DO gula insentif tersebut untuk seorang pemborong PKPN Singkawang, keperluan hari natal, para pegawai Kabupaten, untuk front nasional, KODIM dan keperluan lainnya seperti ongkos pengangkutan, giling, buruh, dan jasa-jasa lain. Sementara untuk kelebihan harga penjualannya oleh terdakwa digunakan untuk pembangunan rumah milik pemerintah daerah. Sehingga dari perbuatan terdakwa Pengadilan Negeri Singkawang dalam Putusannya tanggal 24 September 1964 menghukum (ME) dengan hukuman penjara selama 51 Tahun 6 bulan, namun oleh Pengadilan Tinggi Jakarta dalam Putusannya tertanggal 27 Januari 1965 melepaskan terdakwa dari segala tuntutan hukum, yang diperkuat dengan keluarnya Putusan Mahkamah Agung dengan pertimbangan hukum, “meskipun

\footnotetext{
${ }^{21}$ Indriyanto Seno Adji, 'Perspektif Ajaran Perbuatan Melawan Hukum Terhadap Tindak Pidana Korupsi' (2007) 25 Pro Justisia.[285].
} 
perbuatan terdakwa sunguh merupakan tindakan yang menyimpang dari tujuan yang telah ditentukan oleh yang berwajib namun perbuatan tersebut jika ditinjau dari sudut kemasyarakatan justru menguntungkan masyarakat daerah karena melayani kepentingan umum". ${ }^{22}$ Selain itu penerapan ajaran sifat melawan hukum dalam fungsinya yang negatif juga diterapkan dalam perkara illegal loging dengan terdakwa Lamor Nababan, dimana hakim menggunakan Yurisprudensi dari kasus diatas dimana majelis hakim melihat fakta bahwa kayu-kayu yang diangkut oleh terdakwa akan dipergunakan untuk membangun jembatan antara palangkaraya dan kuala kurun guna memperlancar transportasi pada saat pelaksanaan Pesparawi tingkat provinsi Kalimantan Tengah. Sehingga menurut pandangan hakim secara tidak langsung perbuatan terdakwa sudah melayani kepentingan umum. ${ }^{23}$

Dari pertimbangan yang diberikan oleh hakim maka bisa dilihat hilangnya sifat melawan hukum materil dari pelaku karena tidak adanya keuntungan yang diterima oleh pelaku, terjaminnya kepentingan umum, serta tidak adanya kerugian terhadap negara. ${ }^{24} \mathrm{Hal}$ ini menurut Indriyanto Seno Adji, bahwa ada atau tidaknya kerugian negara tidaklah diartikan sebagai suatu unsur dari rumusan Pasalnya, tetapi penelitian mengenai ada atau tidaknya kerugian negara adalah sebagai salah satu faktor yang menentukan ada atau tidaknya sifat melawan hukum secara materil dari perbuatan si pelaku. ${ }^{25}$

Dari kasus ini, sesuai dengan teori the Pointles Punishment. Teori yang erat kaitannya dengan (the utilitarian theory of excuse). Teori ini mengartikan bahwa "teori hukuman yang tidak perlu".${ }^{26}$ Dari teori ini memandang bahwa tidaklah guna dan bermanfaat apabila memidana seseorang yang dalam dirinya tujuan pemidanaan itu tidak dapat terlaksana (efek jera), serta manfaat yang

${ }^{22}$ Komariah Emong Sapardjaja, Op.Cit.[137-139].

${ }^{23}$ Luh Rina Apriani, 'Luh Rina Apriani, Relevansi Fakta Hukum Dalam Penggunaan Sifat Melawan Hukum Negatif’ (2011) 4 Yudisial.[10].

${ }^{24}$ Didik Endro Purwoleksono, Op.,cit., [188]. 2007).[86].

${ }^{25}$ Indriyanto Seno Adji, Korupsi Kebijakan Aparatur Negara \& Hukum Pidana, (Diadit Media

${ }^{26}$ H. M. Hamdan, Alasan Penghapus Pidana: Teori Dan Studi Kasus (Refika Aditama 2014).[66]. 
diterima (memperbaiki diri) malah tidak tercapai. J. Remmelink yang semula keberatan mengenai hilangnya sifat melawan hukum pidana. Namun melihat perkembangan-perkembangan kasus yang terjadi memahami adanya pengakuan akan asas ini. Sehingga, J. Remmelink memberikan suatu pandangannya terhadap kasus yang terjadi yakni kasus Euthanasia berdasarkan Putusan Hoge Raa N.J 1994.656. Tanggal 21 Juni 1994. Dalam Putusan tersebut Hoge Raad menerima kemungkinan dalam kasus seorang perempuan yang depresi tanpa ciri psikopat. Tenggelam dalam rasa duka berkepanjangan (kehidupan perkawinan yang menyengsarakan anak laki-laki yang bunuh diri, perceraian, matinya anak lakilaki lain karena kanker, percobaan bunuh diri yang kedua kalinya (menyediakan sarana dll). Kendati demikian, banyak yang berpendapat bahwa Hoge Raad dalam kasus ini telah melangkah jauh". Pada akhirnya J. Remmelink menyatakan bahwa "terlalu jauh untuk masih berbicara tentang euthanasia sebagai penghilangan nyawa orang lain yang tidak dibenarkan", ${ }^{27}$

Dalam kasus korupsi pengembalian kerugian keuangan negara akibat di korupsi oleh pelaku sesuai dengan Perma No. 1 Tahun 2020 tepatnya dalam Pasal 8, Pasal 9, dan Pasal 10 yang memberikan kategori terkait kerugian yang ditimbulkan serta pengembalian kerugian keuangan negara tersebut yang hanya sampai pada $50 \%$ sehingga Perma sendirilah yang memberi batasan terhadap pengembalian kerugian tersebut. Tetapi apabila terdakwa karena khilafannya dan dengan segala itikad baik untuk melakukan pemulihan keadaan dari perbuatan yang dilakukannya dengan cara melakukan pengembalian seluruh kerugian keuangan negara maka apakah masih pantas dan adilkah pelaku tersebut untuk tetap dipenjara. Dari permasalah tersebut menimbulkan pro dan kontra yang mana Pandangan yang pertama tetap tidak setuju dan berpegang teguh pada ketentuan yang diatur dalam Pasal 4 UU Tipikor bahwa, Pengembalian kerugian keuangan negara atau perekonomian negara tidak menghapuskan pidananya pelaku tindak pidana sebagaimana diamaksud dalam Pasal 2 dan Pasal 3. Sementara pandangan

${ }^{27}$ Indriyanto Seno Adji, Op.Cit.[287]. 
yang kedua memandang bahwa dengan dikembalikannya kerugian negara, maka tidak terpenuhinya unsur delik tersebut, ialah negara dirugikan, serta melihat pemidanaan yang dilekatkan kepada pelaku sudah tidak tepat lagi karena dengan dipenjara maka kemungkinan pengembalian keuangan negara tidak akan dilakukan oleh pelaku kerena sudah merasa setimpal dengan hukum penjara yang akan dia jalani.

Bertitik tolak dari kedua pandangan ini, penulis sependapat apabila pengembalian kerugian keuangan negara secara menyeluruh menghapus sifat melawan hukum materiel dengan fungsinya yang negatif dari pelaku. Mengingat sesuai dengan yurisprudensi Mahkamah Agung Republik Indonesia, ada kondisi yang menyebabkan hilangnya sifat melawan hukum dari suatu tindak pidana adalah:

1. Terdakwa tidak diuntungkan;

2. Negara tidak dirugikan;

3. Masyarakat dilayani. ${ }^{28}$

Sifat melawan hukum itu sendiri dalam tindak pidana korupsi melanggar suatu kepentingan. Kepentingan yang dimaksud disini adalah kepentingan negara berupa uang negara yang dirugikan. Melihat landasan filosofis yang ingin dilindungi dari UU Tipikor adalah kerugian keuanagan negara. Sehingga dasar dibentuknya KPK itu sendiri untuk bisa mengamankan akan kepentingan negara yang bernilai ekonomis terebut. Olehnya itu, dengan adanya KPK harapannya kerugian yang timbul bisa dipulihkan, atau di ambil kembali keuangan negara. Maka dari itu, dapat dipahami bahwa mengenai sifat melawan hukum materil dalam fungsinya yang negatif dapat menjawab kebutuhan perluasan dari tindak pidana korupsi. Sehingga, praktis maka pengambalian seluruh kerugian keuangan negara dalam kasus tindak pidana korupsi dapat dianggap negara tidak lagi dirugikan. Dengan negara tidak lagi dirugikan maka seyogianya perbuatan pelaku seharusnya menjadi dapat dimaafkan karena hilang sifat melawan hukum materil dalam fungsinya yang negatif. Terlebih putusan hakim

${ }^{28}$ Purwoto Mas Toha Wiku Aji, Umi Rozah Aditya, 'Analisis Sifat Melawan Hukum Dalam Tindak Pidana Korupsi’ (2017) 25 Diponegoro Law Journal.[13]. 
Nomor: 42K/Kr/1965 dalam perkara Machroes Effendi tersebut haruslah menjadi Yurisprudensi \& instrument hukum bagi hakim untuk berani memberikan terobosan hukum manakalah terdapat terdakwa yang telah dengan iktikad baik mengembalikan seluruh kerugian keuangan negara. Sebab, hakim diberikan kewenangan untuk mengunggulkan yurisprudensi melalui "Kontra Legem" hal mana jika hakim benar-benar dapat mengonstruksi cara komparatif analisa bahwa bobot Yurisprudensi lebih potensial menegakkan kelayakan dan perlindungan kepentingan umum, dibanding dengan suatu ketentuan Pasal dalam undangundang, hakim dibenarkan mempertahankan yurisprudensi, terlebih jika terdapat pertentangan antara yurisprudensi dengan ketentuan undang-undang, hakim dapat mempertahankan yurisprudensi dengan tetap menjaga nilai hukum yang terkandung dalam yurisprudensi, dan ketentuan undang-undang diperlunak dari sifat imperatif menjadi fakultatif.

Berangkat dari hal tersebut, sekalipun dalam ketentuan Pasal 4 UU Tipikor menegaskan pengembalian kerugian keuangan negara tidak menghapus perbuatan si pelaku, akan tetapi dengan adanya pendekatan melalui Contra Legem tersebut di atas, hakim memiliki wewenang untuk menentukan bahwa perbuatan pelaku merupakan perbuatan yang tidak lagi melanggar sifat melawan hukum materil dalam fungsinya yang negatif dengan lebih bersandar pada yurisprudensi. Itu sebabnya terdakwa seharusnya dibebaskan. Sekalipun hal tersebut tidaklah mudah, karena masih menimbulkan debatable mengenai sifat melawan hukum materil.

Teori Nigel Walker dan Jeremy Bentham Terkait Hilangnya Sifat Melawan Hukum

Seperti pada bagian sebelumnya sudah penulis paparkan mengenai konsep sifat melawan hukum. Sehingga menimbulkan suatu pergumulan panjang bahkan sampai sekarang ini para praktisi hukum masih dibingungkan baik dari kelompok yang setuju dan tidak setuju terkait hilangnya sifat melawan hukum dalam tindak pidana korupsi setelah dikembalikannya kerugian keuangan negara. 
Yanto Yunus: Hilangnya Sifat Melawan...

Melihat lebih dalam UU Tipikor itu sendiri sebenarnya tidak menempatkan hukum pidana sebagai ultimum remedium karena ketika diteliti dan membaca secara keseluruhan UU Tipikor merupakan salah satu UU yang paling banyak dan sering mengunakan Frasa "Dipidana Penjara" dalam setiap pasalnya. Hal ini menunjukan betapa tidak toleransinya UU tersebut untuk memberikan Perlindungan extra terhadap Kepentingan Negara berupa Keuangan negara. dengan Penempatan hukum Pidana yang notabenenya sebagai ultimum remedium menjadi satu-satunya sarana, jalan untuk menerapkan sanksi hukum kepada pelaku. Pertanyaan penting apakah dengan dikembalikannya kerugian tersebut dengan segala itikad baik yang dimiliki oleh pelaku akan tetap dijatuhi sanksi pidana penjara dibandingkan dengan pelaku yang memilih untuk tidak mengembalikan kerugian yang ditimbulkan akibat perbuatannya.

Terkait apa yang penulis paparkan di atas maka hukum pidana sebagai Ultimum remedium tidak diterapkan sebagaimana mestinya. Dalam teori yang dikemukakan oleh Nigel Walker dan Jeremy Bentham memberikan argumen yang tegas terkait penerapan hukum pidana tersebut, dengan mengatakan bahwa hukum pidana janganlah digunakan untuk:

1. Tujuan pembalasan;

2. Terhadap perbuatan yang tidak menimbulkan korban dan atau kerugian;

3. Bilamana masih ada sarana lain yang lebih efektif dan dengan kerugian yang lebih sedikit dalam menangggulangu perbuatan yang dianggap tercela;

4. Bila dampak negative pidana lebih besar dari pada tindak pidana;

5. Apabila tidak mendapat dukungan publik yang kuat;

6. Apabila sudah diperhitungkan tidak akan berhasil atau tidak akan dapat dilaksanakan. ${ }^{29}$

Selain itu Bentahm juga menegaskan bahwa pidana jangan diterapkan apabila "groundless, neddless, unprofitable, or ineffections". ${ }^{30}$ Sehingga, bertitik tolak dari teori yang dipaparkan diatas sebenarnya menempatkan fungsi hukum pidana itu sendiri sebagai Ultimum remedium atau sebagai langkah terakhir, yang mana dengan dikembalikannya semua kerugian keuangan negara atas tindak pidana

\footnotetext{
${ }^{29}$ Didik Endro Purwoleksono, Op.Cit.[192].

30 ibid.[193].
} 
korupsi yang dilakukan oleh pelaku maka sifat melawan hukum materiel dalam fungsinya yang negatif tersebut tidak melekat lagi pada diri pelaku kerena sudah tidak terpenuhinya salah satu unsur yakni kerugian yang ditimbulkan. Selain itu, melihat lebih jauh dari tujuan diadakannya sanksi pidana adalah efek jera serta pembelajaran yang diterima oleh pelaku sehingga dapat sadar dan insaf akan perbuatan yang dia lakukan. Apabila setelah dilakukan pengembalian seluruh kerugian keuangan negara namun pelaku tetap di pidana penjara maka yang menjadi problem disini ialah kemanfaatan hukum dari penerapan sanksi pidana penjara kepada pelaku korupsi. Hal tersebut sudah tidak sesuai dengan tujuan pemidanaan yakni efek jera dan kemanfaatan dari pidana itu sendiri. Pidana penjara tidak efektif dijatuhkan karena penulis memandang bahwa:

1. Tidak dapat dipulihkannya kerugian keuangan negara;

2. Mengingat bahwa kapasitas lapas yang tidak memadai;

3. Terjadinya perlakuan khusus berupa sel-sel khusus bagi pelaku tipikor;

4. Dan yang lebih penting menekankan kembali makna ultimum remedium hukum pidana itu sendiri dan efek jera bagi pelaku tidak akan tercapai.

Dari argumen dan pandangan tersebut di atas maka Pasal 4 dalam UU Tipikor itu sendiri secara langsung menempatkan bahwa sifat melawan hukum bukan melekat dalam setiap rumusan delik tetapi melekat pada diri pelaku tanpa melihat alasanalasan lainnya yang ada dalam diri pelaku. Maka tepatlah bila kita mengubah mindset dan arah pembangunan kebijakan hukum terkait Pemidanaan.

\section{Kesimpulan}

Tindak pidana korupsi sering merugikan keuangan negara, karena kerugian yang timbul itupun sangat berdampak, dan tentu menghambat pemerintah untuk bisa menjalankan roda pemerintahan karena dana yang sudah dialokasikan disalahgunakan oleh pelaku, sehingga negara sedemikian keras dalam melakukan pencegahan dan pemberantasan tindak pidana korupsi guna mengamankan asset atau keuangan negara dari oknum-oknum tertentu. Sehingga banyak asset hasil korupsi yang diburu oleh penegak hukum untuk dikembalikan. Namun sayangnya banyak asset yang sudah tidak utuh dikembalikan atau bahkan sudah tidak bisa 
diselamatkan oleh negara. Dengan dikembalikannya seluruh asset yang di korupsi tersebut, maka secara tidak langsung sifat melawan hukum sudah tidak terpenuhi dikarenakan negara sudah tidak dirugikan lagi, selain itu terkait penjatuhan sanksi pidana penjara bagi pelaku korupsi dianggap tidak efektif karena berdasarkan teori penjatuhan pidana yang dikemukakan oleh Walker dan Bentham terkait penggunaaan sanksi pidana harus melihat pada manfaaat dari penjatuhan pidana, sehingga berangkat dari teori ini apabila penjatuhan pidana penjara tersebut tidak membawa efek jera bagi diri pelaku maka penjatuhan pidana tersebut tidaklah perlu dilakukan.

\section{Daftar Bacaan}

\section{Buku}

Adami Chazawi, Hukum Pidana Korupsi Di Indonesia (RajaGrafindo Persada 2016).

Bryan A Garner, Black's Law Dictionary $9^{\text {th }}$ ed. (West 2010) Libgen.Ic.Pdf.

Didik Endro Purwoleksono, Hukum Pidana Untaian Pemikiran (Airlangga University Press 2019).

Febby Mutiara Nelson, Plea Bargaining \& Deferred Prosection Agreement dalam Tindak Pidana Korupsi (Sinar Grafika 2020).

H. M. Hamdan, Alasan Penghapus Pidana: Teori dan Studi Kasus (Refika Aditama 2014).

Indriyanto Seno Adji, Korupsi Kebijakan Aparatur Negara $\mathcal{E}$ Hukum Pidana (Diadit Media 2007).

J.M. van Bemmelen, Hukum Pidana 1 (Hukum Pidana Material Bagian Umum) (Binacipta 1987).

Juniver Girsang, Abuse Of Power (JG Publishing 2012).

Jur Andi Hamzah, Pemberantasan Korupsi Melalui Hukum Pidanan Nasional dan Internasional ( RajaGrafindo Persada 2005).

Komariah Emong Sapardjaja, Ajaran Sifat Melawan Hukum Materiel Dalam Hukum Pidana Indonesia (Alumni 2002). 
Peter Mahmud Marzuki, Penelitian Hukum: Edisi Revisi (Kencana 2005).

Pradjonggo, KPHA. Tjandra Sridjaja, Sifat Melawan Hukum dalam Tindak Pidana Korupsi (Indonesia Lawyer Club 2010).

Schaffmeister, N.Keijze, E. PH Sutorius, Hukum Pidana (Konsorsium Ilmu Hukum 1995).

Suhender, Konsep Kerugian Keuangan Negara (Setara Press 2015).

\section{Perundang-undangan}

Undang-Undang No 20 Tahun 2001 tentang Perubahan atas Undang-Undang No. 31 Tahun 1999 tentang Pemberantasan Tindak Pidana Korupsi (Lembaran Negara Republik Indonesia Tahun 2001 Nomor 135).

Kitab Undang-Undang Hukum Pidana Indonesia.

Peraturan Mahkamah Agung Republik Indonesia Nomor 1 Tahun 2020 tentang Pedoman Pemidanaan Pasal 2 dan Pasal 3 Undang-Undang Pemberantasan Tindak Pidana Korupsi.

Surat Kejaksaan Agung Republik Indonesia, No. B-201/f/Fpt/5/199 Jakarta tanggal 04 Mei Tahun 1990, perihal, Petunjuk penyusunan Memori Kasasi atas Putusan Bebas.

\section{Putusan}

Putusan Mahkamah Konstitusi Republik Indonesia Nomor 25/PUU-XIV/2016.

Putusan Mahkamah Agung Republik Indonesia Nomor 42 K/Kr/1965 tanggal 8 Januari 1966.

Putusan Mahkamah Agung Republik Indonesia Nomor 275K/Pid/1983 tanggal 29 Desember 1983.

Putusan Pengadilan Negeri Republik Indonesia Nomor 57/Pid.Sus/TPK/2014/ PN SBY tanggal 3 Juli 2014.

\section{Jurnal}

Seno Adji Indriyanto, 'Perspektif Ajaran Perbuatan Melawan Hukum Terhadap Tindak Pidana Korupsi’ (2007) Pro Justitia.

Titin Apriani, 'Konsep Perbuatan Melawan Hukum Dalam Tindak Pidana' (2019) 


\section{3, GARA.}

Mas Toha Wiku Aji, Umi Rozah Aditya, Purwoto, 'Analisis Sifat Melawan Hukum Dalam Tindak Pidana Korupsi' (2017) 25 Diponegoro law jurnal.

Luh Rina Apriani, 'Relevansi Fakta Hukum Dalam Penggunaan Sifat Melawan Hukum Negatif' (2011) 4 Yudisial.

How to cite: Yanto Yunus, Juwita Sarri dan Syahiruddin, 'Hilangnya Sifat Melawan Hukum Pidana Materil Dalam Tindak Pidana Korupsi Pasca Pengembalian Seluruh Kerugian Keuangan Negara’ (2021) Vol. 4 No. 2 Media Iuris. 